
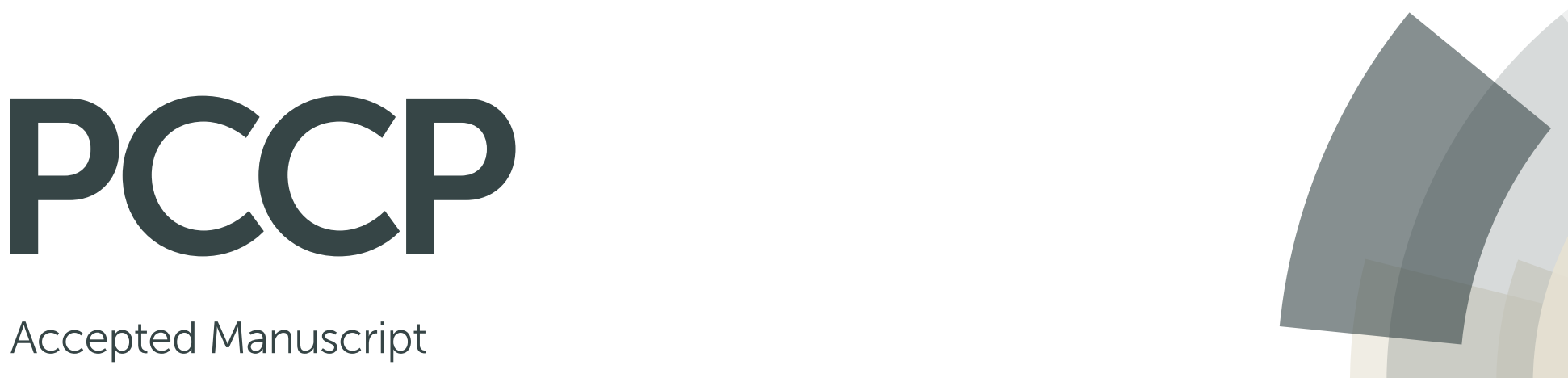

Accepted Manuscript

This article can be cited before page numbers have been issued, to do this please use: G. Janjic, M. Milosavljevi, D. Ž. Veljkovi and S. D. Zaric, Phys. Chem. Chem. Phys., 2017, DOI: 10.1039/C6CP08796E.

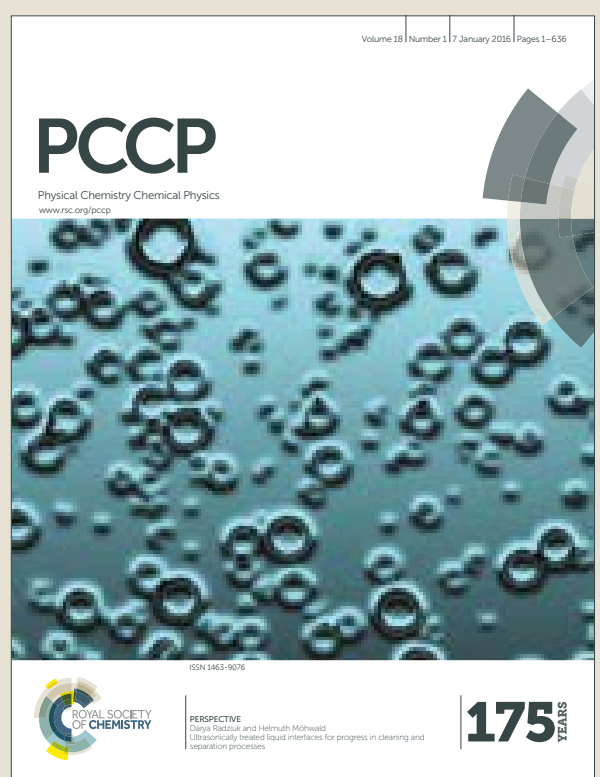

This is an Accepted Manuscript, which has been through the Royal Society of Chemistry peer review process and has been accepted for publication.

Accepted Manuscripts are published online shortly after acceptance, before technical editing, formatting and proof reading. Using this free service, authors can make their results available to the community, in citable form, before we publish the edited article. We will replace this Accepted Manuscript with the edited and formatted Advance Article as soon as it is available.

You can find more information about Accepted Manuscripts in the author guidelines.

Please note that technical editing may introduce minor changes to the text and/or graphics, which may alter content. The journal's standard Terms \& Conditions and the ethical guidelines, outlined in our author and reviewer resource centre, still apply. In no event shall the Royal Society of Chemistry be held responsible for any errors or omissions in this Accepted Manuscript or any consequences arising from the use of any information it contains. 


\section{The Prediction of Strong O-H/M Hydrogen Bonding between Water and Square-planar Ir and Rh Complexes}

Received 00th January 20xx, Accepted 00th January 20xx

\author{
G. V. Janjić, ${ }^{b}$ M. D. Milosavljević, ${ }^{a}$ D. Ž. Veljković, ${ }^{a}$ and S. D. Zarić* ${ }^{a, c}$
}

DOI: $10.1039 / x 0 x \times 00000 x$

www.rsc.org/

Intermolecular $\mathrm{O}-\mathrm{H} / \mathrm{M}$ interactions, between a water molecule and square-planar acac complexes ([M(acac)L2]), with different types of $\mathrm{L}$ ligands (en, $\mathrm{H}_{2} \mathrm{O}, \mathrm{CO}, \mathrm{CN}$-, and $\mathrm{OH}-$ ) and different types of metal atoms (Ir(I), $\mathrm{Rh}(\mathrm{I}), \mathrm{Pt}(\mathrm{II})$, and $\mathrm{Pd}(\mathrm{II})$ were studied by high level ab initio calculations. Among the studied neutral complexes, the $[\mathrm{Pd}(\mathrm{acac})(\mathrm{CN})(\mathrm{CO})]$ complex forms the weakest interaction, $0.62 \mathrm{kcal} / \mathrm{mol}$, while the $[\operatorname{Ir}(\mathrm{acac})(\mathrm{en})]$ complex forms the strongest interaction, $-9.83 \mathrm{kcal} / \mathrm{mol}$, which is remarkably stronger than the conventional hydrogen bond between two water molecules $(-4.84 \mathrm{kcal} / \mathrm{mol})$.

Hydrogen bonding in chemical and biological systems has been investigated intensively. ${ }^{[1-6]}$ Depicted with $\mathrm{X}-\mathrm{H}^{\cdots \cdots} \mathrm{Y}-\mathrm{Z}$ scheme, the hydrogen bond is generally considered to be an attractive interaction between a polarized $\mathrm{X}-\mathrm{H}$ bond $(X$ is more electronegative than $\mathrm{H}$ ) and $\mathrm{a} Y$ atom from $\mathrm{Y}$-Z species. ${ }^{[2,5]}$ The region of high electron density, such as a lone pair of electrons, a $\pi$ molecular orbitals, or a $\sigma$ bonding pair can also constitute a valid acceptor. ${ }^{[2,3]}$ In strong hydrogen bonds, the electrostatic component has the largest contribution to the total energy, while in weak hydrogen bonds, the contribution of the dispersion component is similar or larger than the electrostatic contribution. ${ }^{[4,6]}$

Metal complexes can form non-covalent interactions in a specific way, which contributes to their behavior, including their biological activity. ${ }^{[7]}$ Metals as acceptors were not included in the discussions on hydrogen bonding definition. ${ }^{[5]}$ However, it has become increasingly evident that metals can

\footnotetext{
a. MSc. M. D. Milosavljević,Dr. D. Ž. Veljković, Prof. S. D. Zarić

Department of Chemistry, University of Belgrade

Studentskitrg 12-16,11000 Belgrade, Serbia.

E-mail: szaric@chem.bg.ac.rs

${ }^{b . D r . ~ G . ~ V . ~ J a n j i c ́ ~}$

Institute of Chemistry, Technology and Metallurgy, University of Belgrade,

Njegoševa 12, P.O. Box 473, 11000 Belgrade, Serbia.

'Prof. S. D. Zarić

Department of Chemistry, Texas A \& M University at Qatar,

P.O. Box 23874, Doha, Qatar.

Electronic Supplementary Information (ESI) available: [details of any supplementary information available should be included here]. See DOI: $10.1039 / \mathrm{x} 0 \times x \times 00000 \mathrm{x}$
}

play considerable and varied roles in hydrogen bonding. ${ }^{[8-10]}$ $\mathrm{O}-\mathrm{H} / \mathrm{M}$ interactions were described and reviewed a long time ago. ${ }^{[8 b-8 d]}$ The electron-rich metal ions with filled d-orbitals (typically for late transition metal complexes) are suitable to form hydrogen bonds. ${ }^{[11]}$ There are several papers that emphasize the importance of these interactions and indicate that $\mathrm{X}-\mathrm{H} \cdots \mathrm{M}-\mathrm{L}$ hydrogen bonds have an evident influence on some chemical or physical changes. X-ray diffraction studies indicate that a water molecule can occupy an axial position in square-planar $\mathrm{d}^{8}$ complexes. ${ }^{[12,13]}$ Neutron diffraction studies allowed determination of the accurate position of $\mathrm{H}$ atoms in crystal structures and showed that the water molecule is indeed involved in the hydrogen bonding to the metal. ${ }^{[2,14,15]}$ Spectroscopic features of the hydrogen bonding in X-H'M-L complexes are similar to those found in the case of classical hydrogen bonding: IR stretching frequencies for the $\mathrm{X}-\mathrm{H}$ bonds are decreased and NMR chemical shifts for the $\mathrm{H}$ atoms are shifted downfield. ${ }^{[16]}$ Several theoretical models have been used to explain the strength and nature of these hydrogen bonds. ${ }^{[15,17,18,19]}$

As distinct from a simple electrostatic interaction, hydrogen bonds have also a minor degree of covalency. A DFT/AIM study of X-H'M-L hydrogen bonds ( $\mathrm{X}$ is an $\mathrm{N}$ or $\mathrm{C}$ atom) ${ }^{[19]}$ where the DFT results were checked against experimental NMR data, shows that these hydrogen bonds are electrostatic interactions which developed some covalency at short $\mathrm{H}^{\prime \prime} \mathrm{M}$ distances. An $a b$ initio study, at the MP2 and HF level of theory, on the interactions between a water molecule and neutral platinum(II) complexes indicates that a linear $\mathrm{O}-\mathrm{H} / \mathrm{Pt}$ interaction is stabilized by a strong dispersion component and that covalency does not play an important role in the interaction. ${ }^{[15]}$

In this work, intermolecular O-H/M interactions between a water molecule and square-planar acetylacetonato (acac) complexes were studied by quantum chemical calculations. Since metal acac complexes act as catalysts for different reactions, such as hydrogen oxidation and cyclization reactions, ${ }^{[20]} \mathrm{O}-\mathrm{H} / \mathrm{M}$ interactions can play a role in the reaction mechanisms. To the best of our knowledge, this is the first very 
accurate $a b$ initio study at $\operatorname{CCSD}(\mathrm{T})$ level, aiming to examine the influence of metal type, the charge of metal complex and the nature of $L$ ligands on the strength and nature of $\mathrm{O}-\mathrm{H} / \mathrm{M}$ interactions. The results indicate that some of the complexes can form very strong $\mathrm{O}-\mathrm{H} / \mathrm{M}$ interactions.

To determine the strength of $\mathrm{O}-\mathrm{H} / \mathrm{M}$ hydrogen bonds, the interaction energies for a number of water/metal complex systems were calculated. Although there is a small number of crystal structures with a water molecule involved in $\mathrm{O}-\mathrm{H} / \mathrm{M}$ interactions (Fig. S5b.), water was used in calculations as the hydrogen atom donor because its small size helps to avoid additional non-covalent interactions. The calculations were done in Gaussian09 program. ${ }^{[21]}$ We studied neutral and negative $\left[\mathrm{M}(a c a c) \mathrm{L}_{2}\right]$ complexes (Figure $\mathrm{S} 1$ ) containing different types of $\mathrm{L}$ ligands (en, $\mathrm{H}_{2} \mathrm{O}, \mathrm{CO}, \mathrm{CN}^{-}$and $\mathrm{OH}^{-}$) and different types of metal atoms $\left(\mathrm{Ir}^{+}, \mathrm{Rh}^{+}, \mathrm{Pt}^{2+}\right.$ and $\left.\mathrm{Pd}^{2+}\right)$. The geometry of the model system is shown in Figure 1. The water $\mathrm{O}-\mathrm{H}_{1}$ group is located above the metal atoms and it is orthogonal to the mean plane of the complex, while the $\mathrm{O}-\mathrm{H}_{2}$ group is located above the acac ring. The orientation of the $\mathrm{O}$ $\mathrm{H}_{2}$ group has been chosen to avoid the influence of possible different interactions with ligands $L$, which were varied in the model systems. The interaction energies for various $\mathrm{M} \cdots \mathrm{H}$ distances have been calculated to find the distance with the strongest interaction. The calculations were performed with MP2 method and aug-cc-pVDZ-pp basis set for the metal atom and aug-cc-pVDZ basis set for the other atoms. This method has been used since it is in excellent agreement with the very accurate $\operatorname{CCSD}(\mathrm{T})$ complete basis set (CBS) limit data (SI). The interaction energies at $\operatorname{CCSD}(\mathrm{T}) / \mathrm{CBS}$ level were calculated for the most stable geometries of all the investigated systems (Table 1).

Calculations on the neutral acac complexes of $\operatorname{Ir}(\mathrm{I})$ and $\mathrm{Rh}(\mathrm{I})$ were performed to investigate the influence of the nature of metals and L ligands on the strength of $\mathrm{O}-\mathrm{H} / \mathrm{M}$ interactions. Positive charge of the metal ion is neutralized by the acetylacetonate ion. Three different types of $\mathrm{L}$ ligands (carbonyl ( $\mathrm{CO})$, aqua $\left(\mathrm{H}_{2} \mathrm{O}\right)$ and ethylenediamine (en)) occupy the remaining coordination sites of the complexes. It is well known that $\mathrm{CO}$ ligand is a strong $\pi$-acceptor, while en ligand is a strong electron donor. Aqua and acac are also electron donating ligands, although weaker than en ligand.

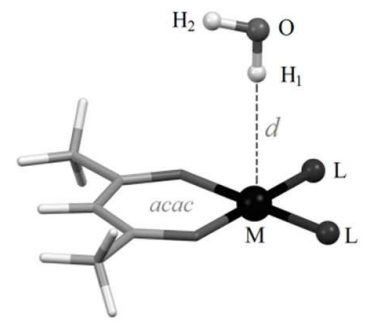

Fig. 1 The model system of the water/metal-complex used for calculations of $\mathrm{O}-\mathrm{H} / \mathrm{M}$ interaction energies.
The data in Table 1 reveal that the interactions of both $\operatorname{Ir}(I)$ and $\mathrm{Rh}(\mathrm{l})$ complexes containing en ligand are the strongest, -9.83 and $-8.95 \mathrm{kcal} / \mathrm{mol}$ respectively, followed by aqua complexes, while complexes with $\mathrm{CO}$ ligands build the weakest $\mathrm{O}-\mathrm{H} / \mathrm{M}$ interactions which are less strong than $3.0 \mathrm{kcal} / \mathrm{mol}$ (Table 1). These results show that the complexes with electron donor ligands build remarkably stronger $\mathrm{O}-\mathrm{H} / \mathrm{M}$ interactions than the complexes with $\pi$-acceptor ligands. The $H \cdots M$ distances ( $d$ distance at Figure 1 ) have the same values for the same type of ligands, regardless of whether the metal atom is $\operatorname{Ir}(\mathrm{I})$ or $\mathrm{Rh}(\mathrm{I})$ (Table 1). The data also show that in case of the same ligands, $\operatorname{Ir}(\mathrm{I})$ complexes form slightly stronger $\mathrm{O}-\mathrm{H} / \mathrm{M}$ interactions (approximately $1.0 \mathrm{kcal} / \mathrm{mol}$ ) than $\mathrm{Rh}(\mathrm{l})$ complexes (Table 1). It is in accordance with the finding that stronger hydrogen bonding occurs at the metal site with higher basicity. ${ }^{[22]}$

We also studied neutral $\mathrm{Pt}(\mathrm{II})$ and $\mathrm{Pd}(\mathrm{II})$ complexes. Because of the different oxidation state of the metals, ligands were also different than in case of $\operatorname{Ir}(\mathrm{I})$ and $\mathrm{Rh}(\mathrm{I})$ complexes (Table 1). The calculations show that $\mathrm{Pt}(\mathrm{II})$ and $\mathrm{Pd}(\mathrm{II})$ complexes form substantially weaker $\mathrm{O}-\mathrm{H} / \mathrm{M}$ interactions (-1.12 and $-0.62 \mathrm{kcal} / \mathrm{mol}$, respectively) than $\operatorname{Ir}(\mathrm{I})$ and $\mathrm{Rh}(\mathrm{I})$ complexes, indicating that the increase of the oxidation state of the metal could lead to weaker interactions. The calculations also show that the $\mathrm{Pt}$ (II) complex forms stronger $\mathrm{O}-\mathrm{H} / \mathrm{M}$ interaction than the $\mathrm{Pd}(\mathrm{II})$ complex (Table 1), in accordance with higher basicity of the $\mathrm{Pt}(\mathrm{II})$ ion. The decrease in the strength of interactions is followed with the increase of H“M distances (Table 1).

These results show that the $\mathrm{O}-\mathrm{H} / \mathrm{M}$ interaction of a water molecule with the $[\operatorname{Ir}(a c a c)(e n)]$ complex is one of the strongest known hydrogen bonds between neutral species. $^{[1,5,9]}$

Energy decomposition analysis (EDA) was performed on all model systems and the results are given in Table 1 . and Table S3.

Table 1.Energies and $\mathrm{H}^{\cdots} \mathrm{M}$ distance (d) of $\mathrm{O}-\mathrm{H} / \mathrm{M}$ interactions. The energies are expressed in $\mathrm{kcal} / \mathrm{mol}$ and the distance in $\AA$.

\begin{tabular}{|c|c|c|c|c|}
\hline Model system & $\Delta \mathrm{E}_{\mathrm{CCSD}(\mathrm{T}) / \mathrm{CBS}}$ & d & $\Delta \mathrm{E}_{\mathrm{ES}}$ & $\Delta \mathrm{E}_{\text {CORR }}^{*}$ \\
\hline \multicolumn{5}{|c|}{ Neutral complexes } \\
\hline$[\operatorname{lr}(\mathrm{acac})(\mathrm{en})]^{\cdots} \mathrm{HOH}$ & -9.83 & 2.3 & -8.62 & -4.85 \\
\hline$\left[\mathrm{Ir}(\right.$ acac $\left.)\left(\mathrm{H}_{2} \mathrm{O}\right)_{2}\right] \cdots " \mathrm{HOH}$ & -6.86 & 2.5 & -5.23 & -2.44 \\
\hline$\left[\operatorname{Ir}(\right.$ acac $\left.)(\mathrm{CO})_{2}\right] \cdots \mathrm{HOH}$ & -2.83 & 2.7 & -0.15 & -2.80 \\
\hline$[\mathrm{Rh}(\mathrm{acac})(\mathrm{en})]{ }^{\prime} \mathrm{HOH}$ & -8.95 & 2.3 & -5.47 & -4.50 \\
\hline$\left[\mathrm{Rh}(\operatorname{acac})\left(\mathrm{H}_{2} \mathrm{O}\right)_{2}\right]{ }^{\cdots} \mathrm{HOH}$ & -5.71 & 2.5 & -2.99 & -4.00 \\
\hline$\left.\left[\mathrm{Rh}(\mathrm{acac})(\mathrm{CO})_{2}\right]\right]^{\prime \prime} \mathrm{HOH}$ & -2.49 & 2.7 & 0.02 & -2.52 \\
\hline$[\mathrm{Pt}(\mathrm{acac})(\mathrm{CN})(\mathrm{CO})]]^{\prime \prime} \mathrm{HOH}$ & -1.12 & 2.7 & 1.69 & -3.26 \\
\hline$[\mathrm{Pd}(\mathrm{acac})(\mathrm{CN})(\mathrm{CO})]^{\prime \prime} \mathrm{HOH}$ & -0.62 & 2.9 & 2.28 & -2.37 \\
\hline \multicolumn{5}{|c|}{ Charged complexes } \\
\hline$[\operatorname{lr}($ acac $)(\mathrm{CN})(\mathrm{CO})]-\cdots \mathrm{HOH}$ & -7.22 & 2.5 & -3.16 & -7.23 \\
\hline$\left[\operatorname{lr}(\text { acac })(\mathrm{CN})_{2}\right]^{2 \cdots \cdots H O H}$ & -12.26 & 2.5 & -8.06 & -6.51 \\
\hline$\left[\operatorname{Ir}(\operatorname{acac})(\mathrm{OH})_{2}\right]^{2-\ldots} \mathrm{HOH}$ & -17.35 & 2.5 & -13.68 & -3.96 \\
\hline
\end{tabular}

$* \Delta \mathrm{E}_{\mathrm{CORR}}=\Delta \mathrm{E}_{\mathrm{CCSD}(\mathrm{T}) / \mathrm{CBS}}-\Delta \mathrm{E}_{\mathrm{HF}}$ 
The results of EDA show that in strong $\mathrm{O}-\mathrm{H} / \mathrm{M}$ bonds the electrostatic component has the largest contribution to the total interaction energy. Table 1 also lists the correlation energy term for $\mathrm{O}-\mathrm{H} / \mathrm{M}$ interactions (which is calculated as the difference between $\mathrm{CCSD}(\mathrm{T}) / \mathrm{CBS}$ and HartreeFock interaction energy) and electrostatic term (calculations of this term are desctibed in SI). The correlation component has a significant contribution to the attraction for complexes with $\mathrm{CO}$ ligands (more than 95\%), while the electrostatic component is very small or even repulsive. For complexes with en ligand, the correlation component has a contribution in the attraction less than $50 \%$, while the electrostatic component is more than $50 \%$. These results are in agreement with the facts saying that for weak hydrogen bonds the correlation component is larger than or similar to the electrostatic component, while the electrostatic component has a rather large contribution in strong hydrogen bonds. ${ }^{[6]}$

It has been shown that the electrostatic potential maps are very useful for understanding interactions of molecules. ${ }^{[23]}$ The electrostatic potential maps for neutral Ir complexes are shown in Figure 2. The interaction energies, as well as electrostatic components (Table 1), correlate qualitatively with the electrostatic potential above a metal atom; the interaction energy increases with increasing the negative potential above a metal atom. The potential above the iridium atom in the en complex is more negative than in the aqua complex, while in the carbonyl complex it is only slightly negative (Figure 2 ). The potential above the platinum and palladium is positive (Figure 3), which leads to repulsion. As mentioned above, despite this electrostatic repulsion, the interactions are attractive because of the correlation component $\left(\Delta \mathrm{E}_{\mathrm{CORR}}\right)$ (Table 1$)$.
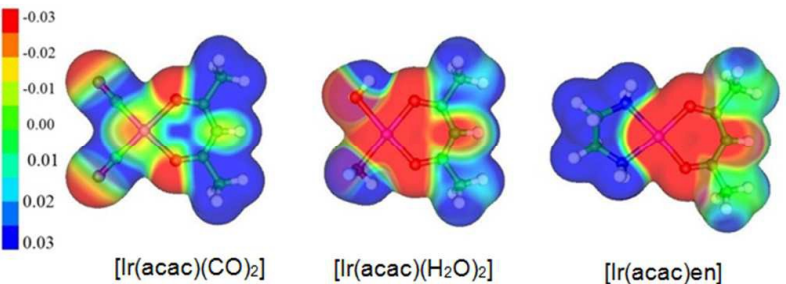

$$
\left[\operatorname{lr}(\operatorname{acac})(\mathrm{CO})_{2}\right]
$$

[Ir(acac)en]

Fig. 2The view of electrostatic potential maps of neutral Ir metal complexes.
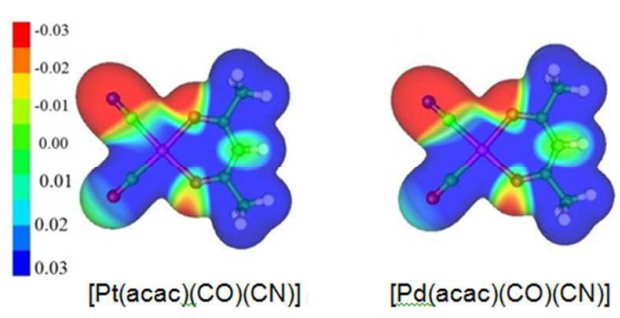

$[\mathrm{Pd}(\mathrm{acac})(\mathrm{CO})(\mathrm{CN})]$

Fig. 3The view of electrostatic potential maps of neutral Pt and Pd metal complexes.

Repulsive character of the $\mathrm{O}-\mathrm{H} / \mathrm{Pt}$ interaction is already described in the system with the positively charged platinum(II) complex. ${ }^{[14]}$ We studied the O-H/M interactions in negatively charged complexes (Table 1 ). The results show that the complexes with negative charge build much stronger

interactions. One can also notice that the $\left[\operatorname{Ir}(\mathrm{acac})(\mathrm{OH})_{2}\right]^{2-}$ complex forms a stronger interaction $(-17.35 \mathrm{kcal} / \mathrm{mol})$ than the $\left[\operatorname{Ir}(\mathrm{acac})(\mathrm{CN})_{2}\right]^{2-}$ complex $(-12.26 \mathrm{kcal} / \mathrm{mol})$, since $\mathrm{CN}^{-}$is the $\pi$-acceptor ligand, while $\mathrm{OH}^{-}$is the $\pi$-donating ligand.

Geometries of model systems studied here are not completely optimized. After geometry optimization without any restrictions, geometries of water/complex systems change (Figure S4). After the optimization, the hydrogen atom from a water molecule builds an additional hydrogen bond with the neighbouring oxygen atom from the acac ring. However, geometries similar to non-optimized water/complex model systems occur in crystal structures (Figure S5).

\section{Conclusions}

On the basis of the computational chemistry results presented above, it can be concluded that the strength of $\mathrm{O}-\mathrm{H} / \mathrm{M}$ interactions depends strongly on the nature of $\mathrm{L}$ ligands and the nature of the metal atom. Unlike the $\pi$-acceptor ligands ( $\mathrm{CO}$ and $\mathrm{CN}^{-}$ligands), the electron donating ligands $\left(\mathrm{H}_{2} \mathrm{O}\right.$, acac, en, $\mathrm{OH}^{-}$ligands) increase the negative potential above the metal atom, and thus increase the acceptor ability of the metal atom and the strength of interactions. Larger oxidation state of the metal, together with $\pi$-acceptor ligands, increases positive potential above the metal atom, decreasing strength of the interaction. As one can assume, the charge of metal complexes has a strong influence on the strength of $\mathrm{O}-\mathrm{H} / \mathrm{M}$ interactions. Surprisingly, the energy of $\mathrm{O}-\mathrm{H} / \mathrm{M}$ interactions in neutral systems with electron donating ligands $\left(\Delta \mathrm{E}_{\mathrm{CCSD}(\mathrm{T}) / \mathrm{CBS}}=-9.83\right.$ $\mathrm{kcal} / \mathrm{mol}$ ), is remarkably larger than the conventional hydrogen bond between two water molecules $\left(\Delta \mathrm{E}_{\mathrm{CCSD}(\mathrm{T}) / \mathrm{CBS}}=-4.84\right.$ $\mathrm{kcal} / \mathrm{mol}) .{ }^{[24]}$ We predicted that these $\mathrm{O}-\mathrm{H} / \mathrm{M}$ interactions could be among the strongest hydrogen bonds between neutral species, indicating the importance of these results.

\section{Acknowledgements}

This work was supported by the Serbian Ministry of Education and Science (grant no. 172065). The HPC resources and services used in this work were partially provided by the IT Research Computing group in Texas A\&M University at Qatar. IT Research Computing is funded by the Qatar Foundation for Education, Science and Community Development (http://www.qf.org.qa).

\section{Notes and references}

¥Footnotes relating to the main text should appear here. These might include comments relevant to but not central to the matter under discussion, limited experimental and spectral data, and crystallographic data.

$\S$

$\S \S$ 
etc.

1 T. Steiner, Angew. Chem. Int. Ed.2002, 41, 48.

2 G. R. Desiraju, Angew. Chem. Int. Ed.2011, 50, 52.

3 a) P. Hobza, Z. Havlas, Theor. Chem. Acc.2002, 108, 325; b) D. Z. Vojislavljević, G. V. Janjić, D. B. Ninković, A.Kapor, S. D. Zarić, CrystEngComm, 2013,15, 2099.

4 C. Pak, H. M. Lee, J. C. Kim, D. Kim, K. S. Kim, Struct. Chem.2005, 16, 187.

5 E. Arunan, G. R. Desiraju, R. A. Klein, J. Sadlej, S. Scheiner, I. Alkorta, D. C. Clary, R. H. Crabtree, J. J. Dannenberg, P. Hobza, H. G. Kjaergaard, A. C. Legon, B. Mennucci, D. J. Nesbitt, Pure Appl. Chem.2011, 83, 1637.

6 B. Paizs, S. Suhai, J. Comput. Chem.1998, 19, 575.

7 a) Y. S. Tan, S. N. A. Halim, K. C. Molloy, A. L. Sudlow, A. Otero-de-la-Roza, E. R. T. Tiekink, CrystEngComm, 2016, 18, 1105; b) E. R. T. Tiekink, Chem. Commun., 2014, 50, 11079; c) T. S. Basu, Baul, S. Kundu, S. Mitra, H. Höpfl, E. R. T. Tiekink, A. Linden, Dalton Trans., 2013, 42, 1905; d) D. P. Malenov, D. B. Ninković, S. D. Zarić, ChemPhysChem, 2015, 16, 761; e) P. V. Petrovic, S. Grimme,S. D. Zaric, M. Pfeffer, J.-P. Djukic, Phys.Chem.Chem.Phys., 2014,16, 14688; f) D. P. Malenov, D. B. Ninković, D. N. Sredojević, S. D. Zarić, ChemPhysChem, 2014, 15, 2458; g) H. Kozlowski, S. Potocki, M. Remelli, M. Rowinska-Zyreka, D. Valensin, Coord. Chem. Rev., 2013, 257, 2625.; h) A. C. Komor, J. K. Barton, Chem. Commun., 2013, 49, 3617; i) T. Gianferrara, I. Bratsosb, E. Alessio, Dalton Trans., 2009, 7588; j) T. C. Johnstone, S. J. Lippard, J. Am. Chem. Soc., 2014, 136 (5), 2126.; k) C. D. Syme, R. C. Nadal, E. J. Stephen, S. E. Rigby, J. H. Viles, J. Biol. Chem.2004, 279, 18169; I) J. T. Pedersen, C. Hureau, L. Hemmingsen, N. H. H. Heegaard, J. Østergaard, M. Vašák, P. Faller, Biochemistry, 2012, 51 (8), 1697; m) C. A. Damante, K. Ösz, Z. Nagy, G. Pappalardo, G. Grasso, G. Impellizzeri, E. Rizzarelli, I. Sóvágó, Inorg. Chem., 2008, 47 (20), 9669.

8 a) M. J. Calhorda, Weak Hydrogen Bonds Involving Transition Elements, Hydrogen Bonding-New Insights, Vol. 3, (Eds.: S. Grabowski), Springer Netherlands, Copyright HolderSpringer, 2006, 245; b) L. Brammer, J. M. Charnock, P. L. Goggin, R. J. Goodfellow, A. G. Orpen, T. F. Koetzle, J. Chem. Soc., Dalton Trans., 1991, 1789; c) M. J. Calhorda, Chem. Commun., 2000, 801; d) G. Orlova, S. Scheiner, Organometallics, 1998,17,4362.

9 L. R. Falvello, Angew. Chem. Int. Ed. 2010, 49, 10045.

10 a) N. V. Belkova, L. M. Epstein, O. A. Filippov, E. S. Shubina, Chem. Rev., 2016, DOI: 10.1021/acs.chemrev.6b00091; b) G. A. Silantyev, O. A. Filippov, P. M. Tolstoy, N. V. Belkova, L. M. Epstein, K. Weisz, E. S. Shubina, Inorg. Chem. 2013, 52 (4), 1787; c) N. V. Belkova, M. Besora, M. Baya, P. A. Dub, L. M. Epstein, A. Lledos, R. Poli, P. O. Revin, E. S. Shubina, Chem. Eur. J. 2008, 14, 9921; d) N. V. Belkova, P. O. Revin, M. Besora, M. Baya, L. M. Epstein, A. Lledos, R. Poli, E. S. Shubina, E. V. Vorontsov, Eur. J. Inorg. Chem. 2006, 2192.

11 L. Brammer, Dalton Trans. 2003, 3145.

12 D. Braga, F. Grepioni, G. R. Desiraju, Chem. Rev. 1998, 98, 1375.

13 M. Baya, ứ. Belío, A. Martín, Inorg. Chem. 2014, 53, 189.

14 J. Kozelka, J. Bergès, R. Attias, J. Fraitag, Angew. Chem. Int. Ed. 2000, 39, 198.

15 S. Rizzato, J. Bergès, S. A. Mason, A. Albinati, J. Kozelka, Angew. Chem. Int. Ed. 2010, 49, 7440.

16 N. V. Belkova, E. S. Shubina, L. M. Epstein, Acc. Chem. Res. 2005, 38, 624.

17 J. Bergès, I. Fourré, J. Pilmé, J. Kozelka, Inorg. Chem. 2013, 52, 1217.

18 P. Vidossich, M. Á. Ortuńo, G. Ujaque, A. Lledōs, ChemPhysChem 2011, 12, 1666.

19 Y. Zhang, J. C. Lewis, R. G. Bergman, J. A. Ellman, E. Oldfield, Organometallics 2006, 25, 3515.
20 a) L. P. Oleksenko, L. A. Belyakova, V. K. Yatsimlrskii, O. Yu. Boldyreva, D. Yu. Lyashenko, Theoretical and Experimental Chemistry 1998, 34, 153; b) M. J. Geier, C. M. Vogels, A. Decken, S. A. Westcott, Eur. J. Inorg. Chem. 2010, 4602; c) G. Bhalla, J. Oxgaard, W. A. Goddard, R. A. Periana, Organometallics 2005, 24, 5499.

21 M. J. Frisch, et al., Gaussian 09, Revision B.01, Gaussian, Inc., Wallingford CT, 2009.

22 D. F. Shriver, Acc. Chem. Res. 1970, 3, 231.

23 a) P. Politzer, J. S. Murray, Cryst.Growth Des. 2015, 5, 3767; b) J. M. Andrić, M. Z. Misini-Ignjatović, J. S. Murray, P. Politzer, Zarić S. D., ChemPhysChem., 2016, 17, 2035.

24 J. M. Andrić, G. V. Janjić, D. B. Ninković, S. D. Zarić, Phys. Chem. Chem. Phys. 2012, 14, 10896-10898. 